УДК 342.95

\author{
I. B. Петрішак \\ orcid.org/0000-0002-9758-3251 \\ здобувач кафедри адміністративного та господарського права \\ Запорізького національного університету
}

\title{
СУДОВІ ОРГАНИ ЯК СУБ'СКТИ ДЕРЖАВНОГО ЗАХИСТУ
}

Актуальність теми дослідження. Судова сфера $€$ однією із найважливіших. Саме на судові органи покладається обов'язок щодо здійснення правосуддя. Судді щоденно виконують завдання, в межах яких приймають рішення, які мають для окремих осіб негативні наслідки, особливо у кримінальних справах, пов'язаних із позбавленням волі. У зв'язку з цим дедалі частіше виникають ситуації, за яких судді потрапляють в зону ризику, проти них або їхніх близьких родичів вчиняються незаконні дії (переслідування, залякування, напади). Саме тому актуальним є дослідження державного механізму захисту та визначення кола осіб, які підпадають під такий захист. Обрана тема дослідження набуває особливої уваги в процесі динамічного розвитку законодавства, постійних реформ, які мають місце в судовій системі.

Аналіз останніх досліджень. Основу дослідження склали висновки провідних вчених у сфері адміністративного права: В.Б. Авер'янова, О.М. Бандурка, М.Н. Берідзе, І.В. Бойко, Ю.П. Битяк, І.П. Голосніченка, С.В. Ківалова, Т.О. Коломоєць, В.К. Колпакова, О.В. Кузьменко, Д.В. Приймаченко, В.В. Прокопенко та інших. Однак значна кількість проблемних питань адміністративно-правового забезпечення державного захисту працівників суду залишається не вирішеною, що свідчить про актуальність обраної теми дослідження.

Постановка завдання (формулювання цілей статті). Метою статті є виокремлення кола осіб, яких наділено правом на отримання державного захисту у зв'язку з роботою в судових органах.

Виклад основного матеріалу. Система особливих заходів державного захисту суддів, працівників правоохоронних органів від перешкоджання виконанню покладених на них законом обов'язків і здійсненню наданих прав, а також від посягань на життя, здоров'я, житло і майно зазначених осіб та їхніх близьких родичів у зв'язку зі службовою діяльністю цих осіб врегульовано Законом України «Про державний захист працівників суду і правоохоронних органів» [1].

Необхідно зазначити, що підходи науковців до визначення поняття «механізм державного регулювання» значно різняться. Так, в одному випадку «механізм державного регулювання» розглядається як поєднання методів, форм, стимулів, інструментів, технологій, які використовує держава [2] (М.Х. Корецький); в інших - як сукупність певних державних регуляторів (Л.С. Головко, Л.І. Дідківська ) [3]; як спосіб дій суб’єкта, набір інструментів, які розв'язують протиріччя (М.А. Латинін) [4]. З.Д. Чуйко під терміном «державний захист» пропонує розуміти створення надійних умов для здійснення чого-небудь; гарантування чого-небудь; захист, охорону кого-небудь або чого-небудь від небезпеки; надання (постачання) чогось кимось у достатній кількості, створення усіх необхідних умов для здійснення чогось, гарантування чогось [5].

3 урахуванням наведеного пропонуємо адміністративно-правовий механізм державного захисту працівників правоохоронних органів та суду розглядати як спосіб погодженого впливу суб'єктів управління на суспільні відносини, пов'язані зі створенням надійних умов для функціонування суддів і правоохоронних органів та гарантування їх охорони від небезпеки.

Для окреслення адміністративно-правового механізму державного захисту працівників суду необхідно встановити коло суб'єктів, яких наділено правом на забезпечення державного захисту. Відповідно до ст. 1 Закону України «Про державний захист працівників суду і правоохоронних органів» можна виокремити такі групи суб'єктів, які мають право на забезпечення державного захисту:

1) до першої групи належать судді Конституційного Суду України, судді та працівники апаратів судів;

2) до другої групи належать працівники правоохоронних органів;

3) до третьої групи належать суб'єкти, які за певних умов мають право на отримання державного захисту;

4) до четвертої групи належать близькі родичі осіб, які відповідають ознакам суб'єктів, яких віднесено до 1-3 групи.

Під захист відповідно до Закону України «Про державний захист працівників суду і правоохоронних органів» підпадають судді Конституційного Суду України, судді та працівники апаратів судів, які беруть безпосередню участь у конституційному провадженні; розгляді справ у судах, кримінальному провадженні та провадженні у справах про адміністративні правопорушення [1]. 
Характеризуючи першу групу суб’єктів, які мають право на забезпечення державного захисту, до якої належать судді Конституційного Суду України, судді та працівники апаратів судів, слід сказати, що правовий статус суддів врегульований Конституцією України [6] та Законом України «Про судоустрій і статус суддів» [7]. Відповідно до ст. 126 Конституції України незалежність і недоторканність судді гарантуються Конституцією й законами України. Забороняється здійснювати вплив на суддю у будь-який спосіб. Держава забезпечує особисту безпеку судді та членів його сім'ї.

Державою забезпечується фінансування та належні умови для функціонування судів і діяльності суддів. Видатки на утримання судів у Державному бюджеті України визначаються окремо (ст. 130 Конституції України) [6]. 3 огляду на зазначене вбачається, що конституційні гарантії державного захисту у вигляді забезпечення особистої безпеки, на відміну від державних заходів захисту, закріплених у Законі України «Про державний захист працівників суду і правоохоронних органів» [1], розповсюджуються виключно на суддів і членів їхніх сімей, категорія ж «працівників суду та членів їхніх сімей» під такий правовий захист згідно положень Основного Закону не підпадає.

Організація судової влади та здійснення правосуддя в Україні врегульовані Законом України «Про судоустрій і статус суддів». Судову владу в Україні реалізовують судді та, у визначених законом випадках, присяжні шляхом здійснення правосуддя у рамках відповідних судових процедур. Національну систему судоустрою складають: 1) місцеві суди; 2) апеляційні суди; 3) Верховний Суд (найвищий суд). Для розгляду окремих категорій справ у системі судоустрою діють вищі спеціалізовані суди, якими $є: 1)$ Вищий суд 3 питань інтелектуальної власності; 2) Вищий антикорупційний суд.

Присяжним є особа, яка у випадках, визначених процесуальним законом, та за її згодою вирішує справи у складі суду разом із суддею або залучається до здійснення правосуддя [7]. Інститут присяжних є виявом участі народу у здійсненні правосуддя. Згідно з ч. 3 ст. 68 Закону України «Про судоустрій і статус суддів» визначено, що на присяжних поширюються гарантії незалежності й недоторканності суддів, встановлені законом, на час виконання ними обов'язків зі здійснення правосуддя. За обгрунтованим клопотанням присяжного заходи безпеки щодо нього можуть вживатися і після закінчення виконання цих обов'язків.

Таким чином маємо ситуацію, за якої в розумінні Закону України «Про судоустрій і статус суддів» присяжний не є суддею, одночасно норми цього закону прямо вказують на поширення гарантій незалежності і недоторканності суддів, встановлених законом (в тому числі, щодо захо- дів безпеки) на присяжних під час виконання ними обов'язків зі здійснення правосуддя, а в деяких випадках - i після закінчення виконання цих обов’язків. При цьому Закон України «Про державний захист працівників суду і правоохоронних органів» взагалі не містить положень про присяжних. 3 огляду на зазначене, було б доречно поширити дію норм Закону України «Про державний захист працівників суду і правоохоронних органів» ще й на присяжних, які також здійснюють правосуддя і підпадають під ті ж самі ризики й загрози, що й судді. Для цього пропонується внести відповідні зміни до ст. 126 Конституції України та в Закон України «Про державний захист працівників суду і правоохоронних органів».

Способами забезпечення незалежності судді є: 1) особливий порядок призначення, притягнення до відповідальності, звільнення та припинення повноважень; 2) недоторканність та імунітетом судді; 3) незмінюваність судді; 4) порядок здійснення правосуддя, визначений процесуальним законом, таємниця ухвалення судового рішення; 5) заборона втручання у здійснення правосуддя; 6) відповідальність за неповагу до суду чи судді; 7) окремий порядок фінансування та організаційного забезпечення діяльності судів, встановленим законом; 8) належне матеріальне та соціальне забезпечення судді; 9) функціонування органівсуддівськоговрядуваннятасамоврядування; 10) визначені законом засоби забезпечення особистої безпеки судді, членів його сім'ї, майна, а також інші засоби їх правового захисту; 11) право судді на відставку.

На органи державної влади, органи місцевого самоврядування, їх посадових та службових осіб, а також фізичних і юридичних осіб та їхні об'єднання покладено обов'язок поважати незалежність суддів і не посягати на неї. За національним законодавством суддею є громадянин України, який відповідно до Конституції України та Закону України «Про судоустрій і статус суддів» призначений суддею, займає штатну суддівську посаду в одному з судів України і здійснює правосуддя на професійній основі. Судді в Україні мають єдиний статус незалежно від місця суду в системі судоустрою чи адміністративної посади, яку суддя обіймає в суді [7].

Щодо функціонування Конституційного Суду України варто зазначити, що йому притаманне власне нормативно-правове регулювання, окреме фінансування, особливості здійснення діяльності. Про Конституційний Суд України в Законі України «Про судоустрій і статус суддів» [7] не зазначається жодного слова. Серед вчених немає єдиної думки щодо місця КСУ в системі державних органів загалом і правосуддя зокрема. Так, B.I. Мусіяка під час аналізу проблем імплементації змін до Конституції України щодо правосуддя 
та статусу Конституційного Суду України вказує на виведення Конституційного Суду України із системи правосуддя і визначає розгляд справ за конституційними скаргами осіб як позасудовий інститут захисту прав і свобод. Автор зауважує, що до внесення змін до Конституції щодо правосуддя конституційно-правова доктрина базувалася на сприйнятті Конституційного Суду України як органу конституційного судочинства. Після внесення змін до Основного Закону Конституційний Суд України остаточно втратив офіційні о3наки належності до органів судочинства, нині у його компетенції - виключно конституційний контроль [8, с. 39].

О.Ю. Водянніков щодо реформування статусу Конституційного Суду України наголошує, що він був виведений із системи судочинства і поставлений над всіма трьома гілками влади [9]. I. Берестова з урахуванням думок сучасних вітчизняних правників, фахівців у галузі конституціонального права доходить обгрунтованого висновку про приналежність Конституційного Суду України до так званих «інших юрисдикційних органів із конституційним статусом, який захищає права й свободи людини і громадянина як останній уповноважений на це державний орган на національному рівні». На підтвердження цього авторка посилається на зміст ст.ст. 55, 159 Конституції України і положення Закону України «Про Конституційний Суд України» [10, с. 157].

На рівні нормативно-правових актів діяльність Конституційного Суду України регулюється розділом XII Конституції України [6], Законом України «Про Конституційний Суд України» [11] та Регламентом Конституційного суду України, ухваленим на спеціальному пленарному засіданні Конституційного Суду України Постановою Конституційного Суду України від 22 лютого 2018 року № 1 -пс/2018 [11].

Конституційний Суд України вирішує питання про відповідність Конституції України законів України та у передбачених Основним Законом випадках інших актів, здійснює офіційне тлумачення Конституції України, а також інші повноваження відповідно до неї. Держава забезпечує особисту безпеку судді Конституційного Суду України та членів його сім’ї [6]. В розумінні Закону України «Про Конституційний Суд України» КСУ є органом конституційної юрисдикції, який забезпечує верховенство Конституції України, вирішує питання про відповідність Конституції України законів України та у передбачених Конституцією України випадках інших актів, здійснюе офіційне тлумачення Конституції України, а також інші повноваження відповідно до неї.

Відповідно до ст. 25 Закону України «Про Конституційний Суд України», яка має назву «Гарантії безпеки судді Конституційного Суду та членів його сім'і», зазначено, що безпека судді КСУ та членів його сім'ї (батьків, чоловіка / дружини, дітей) перебуває під особливим захистом держави. Органи правопорядку вживають заходів для безпеки судді та членів його сім'ї за наявності відповідної заяви судді. Вчинені у зв'язку з діяльністю судді посягання на його життя і здоров'я, погроза вбивством, насильством і вчинення таких самих дій щодо членів його сім'ї мають наслідком відповідальність, встановлену законом [12].

За загальним правилом відповідно до Закону України «Про державний захист працівників суду і правоохоронних органів» захисту підлягають близькі родичі (батьки, дружина (чоловік), діти, рідні брати і сестри, дід, баба, онуки) суддів і працівників правоохоронних органів, посягання на життя, здоров'я, житло і майно яких перешкоджає виконанню працівниками суду й правоохоронних органів покладених на них законом обов'язків і здійсненню наданих прав. Виняток становить захист членів сім'ї судді Конституційного Суду України, який поширюється лише на батьків, чоловіка / дружину, дітей. Вважаємо, що такі обмеження кола близьких родичів мають дискримінаційний характер. 3 урахуванням цього пропонуємо внести зміни в закони України, поширивши дію захисту на близьких родичів суддів Конституційного Суду України.

Враховуючи відсутність прямих посилань у Конституції України та законах України про віднесення Конституційного Суду України до системи правосуддя, доцільного говорити про перегляд положень Закону України «Про державний захист працівників суду і правоохоронних органів» в частині регулювання державного захисту суддів Конституційного Суду України. Щодо працівників апарату суду, то до них віднесено голову апарату суду, його заступників, працівників управління, відділів, секторів, що здійснюють свої функції на підставі положень, які затверджуються керівником апарату відповідного суду, секретарі судового засідання, наукові консультанти та судові розпорядники [13].

Щодо помічника судді, то ним може бути працівник апарату суду, який є патронатним службовцем у суді, що забезпечує виконання суддею повноважень щодо здійснення правосуддя [14]. Cекретар судового засідання $\epsilon$ посадовою особою апарату суду, який забезпечує організаційний аспект розгляду адміністративної справи [15]. Судовий розпорядник також належить до апарату суду та $€$ працівником служби судових розпорядників, який забезпечує додержання особами, які перебувають у суді, встановлених правил, виконання ними розпоряджень головуючого в судовому засіданні [7].

Судді, працівники суду та їхні близькі родичі підлягають державному захисту лише за наявності певних підстав та умов: 1) чітке визначення 
та віднесення на рівні закону категорії посади та відповідно родича або члена сім’ї, на яких поширюється такий захист; 2) безпосередня участь судді, працівника суду в конституційному провадженні, розгляді справ у судах, кримінальному провадженні та провадженні у справах про адміністративні правопорушення; 3) наявність відомостей про перешкоджання виконанню покладених на працівників суду та правоохоронних органів обов'язків і здійсненню наданих прав; 4) наявність даних про існування реальної загрози життю, здоров'ю або майну працівників суду та правоохоронних органів та їхніх близьких родичів у зв'язку зі службовою діяльністю цих осіб; 5) зв'язок між протиправними діями, зазначеними в пунктах 3,4 , пов'язаними 3 діяльністю працівника суду або правоохоронних органів. При цьому приводом для вжиття спеціальних заходів щодо забезпечення безпеки працівника суду та його близьких родичів може бути: 1) заява працівника або його близького родича; 2) звернення керівника відповідного державного органу; 3) отримання оперативної та іншої інформації про наявність загрози життю, здоров'ю, житлу і майну осіб, які підлягають захисту.

Висновки 3 дослідження та перспективи подальших розвідок у цьому напрямі. Проведене дослідження дало змогу виділити осіб, які підпадають під державний захист, діяльність яких пов' язано із правосуддям. До них віднесено: 1) суддів місцевих, апеляційних судів, Верховного Суду, Вищого суду з питань інтелектуальної власності, а також Вищого антикорупційного суду; 2) працівників апаратів місцевих, апеляційних судів, Верховного Суду, Вищого суду з питань інтелектуальної власності, а також Вищого антикорупційного суду (зокрема, голова апарату суду, його заступники, працівники управління, відділів, секторів, секретарі судового засідання, наукові консультанти та судові розпорядники); 3) близьких родичів суддів і працівників апаратів місцевих, апеляційних судів, Верховного Суду, Вищого суду з питань інтелектуальної власності, а також Вищого антикорупційного суду (батьки, дружина (чоловік), діти, рідні брати і сестри, дід, баба, онуки).

Однак зазначені вище особи підлягають державному захисту лише за наявності певних підстав та умов, а саме: 1) чітке визначення та віднесення на рівні закону категорії посади та родича або члена сім'ї, на яких поширюється такий захист; 2) безпосередня участь судді, працівника суду в конституційному провадженні, розгляді справ у судах, кримінальному провадженні та провадженні у справах про адміністративні правопорушення; 3) наявність відомостей про перешкоджання виконанню покладених на працівників суду та правоохоронних органів обов'язків і здійсненню наданих прав; 4) наявність даних про існування реальної загрози життю, здоров'ю, або майну працівників суду та правоохоронних органів і їхніх близьких родичів у зв'язку зі службовою діяльністю цих осіб; 5) зв'язок між протиправними діями, зазначеними в пунктах 3,4 , із діяльністю працівника суду або правоохоронних органів. Визначено, що Конституційний Суд України є органом, який наділений особливим статусом і реалізує конституційну юрисдикцію. Державному захисту підлягають судді Конституційного Суду України та члени їхніх сімей (батьки, чоловік / дружина, діти).

\section{Jimepamypa}

1. Про державний захист працівників суду і правоохоронних органів : Закон України від 23.12.1993 № 3781-XII. URL: http://zakon3.rada.gov.ua/laws/ show/3781-12 (дата звернення: 10.09.2020).

2. Корецький М.X. Державне управління аграрної сфери у ринковій економіці / М.Х. Корецький. К. : Вид-во УАДУ, 2002. 260 с.

3. Дідківська Л.І. Державне регулювання економіки : навч. посіб. / Л.І. Дідківська, Л.С. Головко. К. : Знання-Прес, 2000. 209 с.

4. Латинін М.А. Аграрний сектор економіки України: механізм державного регулювання : монографія / М.А. Латинін. Х. : Магістр, 2006. 320 с.

5. Чуйко З.Д. Конституційно-правовий механізм забезпечення національної безпеки України. Бюлетень Міністерства юстииї України. 2006. № 8. С. 85.

6. Конституція України. Відомості Верховної Ради України (ВВР). 1996. № 30. С. 141.

7. Про судоустрій і статус суддів : Закон України від 02.06.2016 № 1402-VIII. Дата оновлення: 20.06.2020. URL: https://zakon.rada.gov.ua/laws/show/140219\#Text.

8. Мусіяка В. Чи є Конституційний суд судом. URL: https://dt.ua/internal/chi-ye-konstituciyniysudsudom-243696.html.

9. Водяніков О. Відчиняючи двері Конституційного Суду: конституційна скарга як нова можливість захисту конституційних прав. URL: https://ukr.lb.ua/blog/ oleksandr_vodennikov/371421_vidchinyayuchi_dveri_ konstitutsiynogo.html.

10. Берестова I. Конституційний Суд України в системі юрисдикційних органів: загальні положення. Підприєлництво, господарство і право. № 9. 2018. URL: http://pgp-journal.kiev.ua/archive/2018/9/29.pdf.

11. Регламент Конституційного Суду України : Постанова Конституційного Суду України про Регламент Конституційного Суду України від 22.02.2018 № 1-пс/2018. 20.06.2020. URL: https://zakon.rada. gov.ua/laws/show/v0001710-18\#n12.

12. Про Конституційний Суд України : Закон України від 13.07.2017 № 2136-VIII. URL: https://zakon.rada.gov.ua/laws/show/2136-19.

13. Про затвердження Типового положення про апарат суду : Наказ Державної судової адміністрації України від 08.02.2019 № 131. URL: https://zakon.rada.gov. ua/rada/show/v0131750-19\#Text.

14. Положення про помічника судді : Рішення Ради суддів України від 18.05.2018 № 21. Дата оновлення: 22.11.2019. URL: https://zakon.rada.gov.ua/rada/ show/vr021414-18\#Text.

15. Типова посадова інструкція секретаря судового засідання місцевого загального суду : Наказ Держав- 
ної судової адміністрації України від 20.07.2005 № 86. URL: https://zakon.rada.gov.ua/rada/show/v008675005\#Text.

\section{Анотація}

Петрішак I. В. Судові органи як суб'єкти державного захисту. - Стаття.

Статтю присвячено висвітленню питань, пов'язаних зі встановленням сутнісних характеристик державного захисту працівників суду шляхом визначення адміністративно-правового механізму державного захисту. Здійснено аналіз нормативно-правових актів, якими врегульовано правовий статус судових органів як суб'єктів державного захисту. Визначено, що адміністративно-правовим механізмом державного захисту працівників правоохоронних органів та суду є спосіб погодженого впливу суб'єктів управління на суспільні відносини, пов'язані зі створенням надійних умов для функціонування суддів і правоохоронних органів та гарантування їх охорони від небезпеки.

Встановлено, що в законодавстві немає єдиного підходу до визначення суб'єктів, які підлягають державному захисту. Виокремлено чотири групи суб'єктів, які мають право на забезпечення державного захисту. До першої групи суб'єктів, які мають право на забезпечення державного захисту, належать судді Конституційного Суду України, судді та працівники апаратів судів. До другої групи суб'єктів, які мають право на забезпечення державного захисту, запропоновано віднести працівників правоохоронних органів. Суб'єктів, які мають право на забезпечення державного захисту, віднесено до третьої групи. До четвертої групи належать суб'єкти, які мають право на забезпечення державного захисту щодо близьких родичів та осіб, які відповідають ознакам суб'єктів, яких віднесено до 1-3 групи.

Визначено, що способами забезпечення незалежності судді є: 1) особливий порядок призначення, притягнення до відповідальності, звільнення та припинення повноважень; 2) недоторканність та імунітетом судді; 3) незмінюваність судді; 4) порядок здійснення правосуддя, визначеним процесуальним законом, таємниця ухвалення судового рішення; 5) заборона втручання у здійснення правосуддя; 6) відповідальність за неповагу до суду чи судді; 7) окремий порядок фінансування та організаційного забезпечення діяльності судів, установленим законом; 8) належне матеріальне та соціальне забезпечення судді; 9) функціонування органів суддівського врядування та самоврядування; 10) визначені законом засоби забезпечення особистої безпеки судді, членів його сім'ї, майна, а також інші засоби їх правового захисту; 11)право судді на відставку.
Ключові слова: державний захист, працівник, суд, правоохоронний орган, правовий статус, механізм, апарат, Конституційний Суд, судові органи, правосуддя.

\section{Summary}

Petrishak I. V. Judicial authorities as subjects of state protection. - Article.

The article is devoted to the issues related to the establishment of the essential characteristics of the state protection of court employees by determining the administrative and legal mechanism of their state protection. An analysis of normative legal acts regulating the legal status of judicial bodies as a subject of state protection has been carried out.

It is determined that the administrative and legal mechanism of state protection of law enforcement officers and courts is a way of coordinated influence of government entities on public relations, which are related to creating reliable conditions for judges and law enforcement agencies and guaranteeing their protection from danger.

It is established that the legislation does not have a single approach to the definition of subjects subject to state protection. There are four groups of entities that have the right to state protection. The first group of subjects entitled to state protection includes judges of the Constitutional Court of Ukraine, judges and court staff. The second group of entities that have the right to state protection is proposed to include law enforcement officers. entities that have the right to provide state protection The fourth group of entities that have the right to provide state protection includes close relatives of persons who meet the characteristics of entities that are assigned to 1-3 groups.

It is determined that the ways to ensure the independence of a judge are: 1) a special procedure for appointment, prosecution, dismissal and termination of powers; 2 ) immunity and immunity of a judge; 3 ) the immutability of the judge; 4 ) the procedure for the administration of justice determined by the procedural law, the secrecy of a court decision; 5) prohibition of interference in the administration of justice; 6 ) liability for contempt of court or judge; 7) a separate procedure for financing and organizational support of the activity of courts established by law; 8) proper material and social security of the judge; 9) functioning of judicial and self-government bodies; 10) the means of ensuring the personal safety of a judge, members of his family, property, as well as other means of their legal protection determined by law; 11) the right of a judge to resign.

Key words: state protection, employee, court, law enforcement body, legal status, mechanism, apparatus, Constitutional Court, judicial bodies, justice. 